anales de psicología, 2018, vol. 34, $\mathrm{n}^{\circ} 2$ (may), 405-411 http://dx.doi.org/10.6018/analesps.34.2.291711
(C) Copyright 2018: Editum. Servicio de Publicaciones de la Universidad de Murcia. Murcia (Spain) ISSN print edition: 0212-9728. ISSN web edition (http://revistas.um.es/analesps): 1695-2294

\title{
Assessing teacher leadership in physical education: the Spanish version of the transfor- mational teaching questionnaire
}

\author{
Octavio Álvarez ${ }^{1}$ Inés Tomás ${ }^{2 *}$, Isaac Estevan ${ }^{3}$, Javier Molina-García ${ }^{3}$, Ana Queralt ${ }^{4}$, and Isabel Castillo ${ }^{1}$ \\ 1 Department of Social Psychology. University of Valencia (Spain). \\ 2 Department of Methodology of Behavioural Sciences. University of V alencia (Spain). \\ 3 Department of Teaching of Music, Visual and Corporal Expression. University of $V$ alencia (Spain). \\ 4 Department of Nursing. University of Valencia (Spain).
}

\begin{abstract}
Título: Evaluación del liderazgo del profesor de educación física: Versión española del cuestionario de enseñanza transformacional.

Resumen: Desde la teoría del liderazgo transformacional, en este estudio se traduce y analizan las propiedades psicométricas de la versión española del Cuestionario de Enseñanza Transformacional (TTQ).

Un total de 2107 adolescentes (997 hombres y 1110 mujeres) de 82 institutos de secundaria participaron voluntariamente en la investigación.

En el estudio 1 ( $n=1066)$, el análisis factorial exploratorio informó de una solución unifactorial. En el estudio $2(n=1041)$, los análisis factoriales confirmatorios mostraron índices de ajuste adecuados, replicándose la estructura de cuatro factores de la enseñanza transformacional con un factor de segundo orden hallada con adolescentes canadienses. La consistencia interna de las subescalas y de la escala total fue adecuada. Se confirmaron las relaciones hipotetizadas con otras variables y se obtuvo evidencia de la invarianza factorial por género.

El estudio ofrece evidencia de la validación cross-cultural del TTQ, un cuestionario diseñado para evaluar la percepción que tienen los estudiantes de las conductas de sus profesores desde la perspectiva de la teoría del liderazgo transformacional. Los resultados sugieren que la versión española de TTQ puede ser utilizada para evaluar la enseñanza transformacional en las clases de educación física en adolescentes españoles.

Palabras clave: Teoría liderazgo transformacional; enseñanza transformacional; educación física; adaptación escala; adolescentes.
\end{abstract}

\section{Introduction}

Physical education (PE) classes become a fundamental context for promoting youth's physical activity (PA) participation. PE lessons are presented to adolescents of all level of abilities as a mandatory subject in most school countries systems. Positive experiences in PE may be important not only to encourage health benefits by helping them meet current PA recommendations (WHO, 2010), but also in promoting lifelong PA habits, which can impact on future public health (Molina-García, Queralt, Estevan, \& Sallis, 2016). Thus, effective experiences in $\mathrm{PE}$ classes seem an important arena for children and adolescents health, and PE teachers' behaviours have considerable potential to impact in the motivational, affective and behavioural responses of their students. Transformational leadership theory (Bass, 1985; Burns, 1978) has been the most studied paradigm for understanding the effects of leaders' behaviours on their followers in the field of applied psychology (Álvarez, Lila, Tomás, \& Castillo, 2016; Beauchamp \& Morton, 2011, Molero, Cuadrado, Navas, \& Morales, 2007). This theory emphasizes on leadership

* Correspondence address [Dirección para correspondencia]: Inés Tomás. Department of Methodology of Behavioural Sciences. Faculty of Psychology, University of Valencia. Avda. Blasco Ibañez, 21, 46010 Valencia (Spain). E-mail: Ines.Tomas@uv.es
Abstract: Drawing from the transformational leadership theory, this study aims to translate and analyse the psychometric properties of a Spanish version of the Transformational Teaching Questionnaire (TTQ).

A cohort sample of 2107 adolescents (997 males and 1110 females) from 82 secondary schools voluntarily participated in the research.

In Study $1(n=1066)$, the exploratory factor analysis informed a onefactor solution. In Study $2(n=1041)$, the confirmatory factor analysis showed the single-factor and the four-factor models showed satisfactory and adequate goodness of fit indices, respectively. Confirmatory factor analysis demonstrated that the four-factor structure of transformational teaching with a high second-order factor, previously found in Canadian adolescents, was replicated in this study. Internal consistency was high in all subscales and in the total scale. The expected pattern of significant relationships with other variables was supported, and evidence of measurement invariance across gender groups was obtained.

This study provides evidence for the cross-cultural validation of the TTQ, a questionnaire designed to assess students' perceptions of their teachers' behaviours from the perspective of transformational leadership theory. These findings suggested that the Spanish version of TTQ would be useful for assessing transformational teaching in Spanish adolescents in physical education classes.

Keywords: Transformational leadership theory; transformational teaching; physical education; scale adaptation; adolescents.

styles as a way to enhance followers' intrinsic motivation and development.

Burns (1978) set the stage for the evolution of the transformational leadership (TL) concept and was subsequently developed by Bass and colleagues (Bass, 1985, Bass \& Avolio, 1995) trying to response to the lack of empirical evidence to support Burns' theory. According to Bass and Riggio (2006), transformational leaders play a positive role model (idealized influence); they are able to inspire followers to move into action to create a shared vision, aligning the vision and the goals of the follower with the goals and needs of the group (inspirational motivation). Transformational leaders are concerned about being in tune with the followers' needs and goals, are ready to understand the followers' strengths, to pull out those strengths, and to satisfy the followers' personal goals (individual consideration). And finally, leaders also stimulate followers to think in different ways to face new and old challenges and issues; dissension is not only permitted but stimulated (intellectual stimulation).

TL has been studied extensively in a diverse range of work settings (Barling, Christie, \& Hoption, 2011) such as the organizational contexts (Molero, Recio, \& Cuadrado, 2010; Molero et al., 2007), police settings (Álvarez, Lila, Tomás, \& Castillo, 2014; Densten, 2003), and also including the educational domains (Beauchaump et al., 2014). There- 
fore, TL theory represents a theoretical framework that can be applied to understand the effects of teachers' leadership on their students in the field of PE (Álvarez et al., 2016; Beauchamp \& Morton, 2011). In fact, one of the most recent applications of the TL theory has been made into adolescent PE and health promotion settings; and has been called Transformational Teaching (Beauchamp et al., 2010, 2014; Beauchamp \& Morton 2011; Wilson et al., 2012). This teaching style involves 'the demonstration of behaviours that empower and inspire students, transcend teachers' own self-interests, and give students the confidence to achieve higher levels of functioning' (Beauchamp \& Morton, 2011, p. 133). Beauchamp and Morton (2011) developed a conceptual model regarding to proximal (withinschool) and distal (out-of-school) effects. This model suggested that transformational behaviours displayed by school $\mathrm{PE}$ teachers enhanced engagement in PA within the PE class (proximal effect) and in PA in their leisure time (distal effect) in adolescents.

To evaluate transformational teaching, Beauchamp and colleagues (2010) developed and validated the Transformational Teaching Questionnaire (TTQ) in Canadian adolescents. This instrument measures four dimensions of transformational leadership (Idealized Influence, Inspirational Motivation, Intellectual Stimulation and Individual Consideration). The authors tested a model with the four dimensions specified as correlated first-order latent factors. However, each of the four factors were found to be highly correlated $(r$ $>$.86) for what they decided to examine a second-order model, in which four first-order dimensions were specified as contributing towards a higher order latent variable, termed transformational teaching. Each of the subscales and the total scale were found to demonstrate good internal consistency $(\square \mathrm{s}>.85)$.

Transformational teaching behaviours have been found to predict student self-determined motivation, positive affect responses and engagement (Beauchamp et al., 2010; Beauchamp \& Morton, 2011; Wilson et al., 2012). Previous researchers found that transformational teaching behaviours were positively related to adaptive cognitive (belief and attitudes toward PE, motivation toward PE and PA), emotional (enjoyment of PE, satisfaction with the teacher), and behavioural (effort in-class of PA and leisure time on PA) responses among adolescents (e.g., Beauchamp et al., 2010). The tenets of TL have been tested with intervention programs (Beauchamp et al., 2011) aiming at modifying the behaviours of PE teachers towards the transformational style, in order to promote self-determined motivation, self-efficacy and the intention to remain physically active in adolescent students. In Beauchamp et al's (2011) study, two months after the intervention (time 2), there was an increase in transformational teaching practices and improvements in all three dependent variables (self-determined motivation, self-efficacy and the intention to remain physically active) in the experimental group. Four months after the intervention (time 3), the improvement in self-determined motivation was maintained.

Considering previous empirical evidence, we would ex- pect that TTQ scores will be related to motivational regulations. Concretely, we will hypothesize that student's perceptions of transformational teaching will be positively associated with the most self-determined forms of motivation (intrinsic motivation and identified regulation) and negatively associated with the lowest self-determined forms of motivation (external regulation and amotivation). We would also expect that TTQ scores will show significant and positive relationship with enjoyment; significant and negative relationship will be expected with boredom.

Making summary of the ideas that have been introduced so far, we could say that transformational teaching is a key factor to enhance students' PA inside and outside the school. In this line, it is clearly important to assess transformational teaching in the PA context. However, as far as we know, the translation and psychometric properties of a Spanish version of the scale in PE are yet to be established. Thus, the development of a Spanish version of the TTQ would cover a gap in the PA measurement field. The aim of the present study using samples of adolescents, in PE context, was twofold: (1) to translate the TTQ items into Spanish and examine the factor structure and reliability of the Spanish version of the TTQ, and (2) to confirm the factor structure of the TTQ, examine the reliability, test the TTQ invariance across gender, and provide evidence of validity based on the relationships with other variables.

Test translation and adaptation is a major concern in psychometric research (Balluerka, Gorostiaga, Alonso-Arbiol, \& Haranburu, 2007; Muñiz, Elosua, \& Hambleton, 2013) that will facilitate cross-cultural comparative research and should help in understanding diverse cultural variations. Testing for gender invariance would contribute to the TTQ validation process as far as the study of gender differences in followers' perceptions of the leader have been raised as an interesting topic (e.g., Antonakis et al., 2004); thus, future research could be interested in testing gender differences in the students' perceptions of teacher's leadership style.

\section{Method}

\section{Participants}

Study 1. 1066 secondary school students (502 males, 564 females; $M_{\text {age }}=16.81$ years; $S D=0.71$, range 16-18), from 40 secondary schools from Valencian Community (Spain) volunteered to participate in this study.

Study 2. 1041 adolescents (495 males, 546 females; $M_{\text {age }}$ $=16.83$ years; $S D=0.70$, range 16-18) across 42 secondary schools from Valencian Community (Spain) volunteered to participate in this study.

\section{Instruments}

Students' perceptions of their teachers' behaviours were measured using the Transformational Teaching Questionnaire (TTQ; Beauchamp et al., 2010). The TTQ begins with 
the stem 'My physical education teacher...' and use a 5-point scale with anchors 1 (Not at all), 2 (Once in a while), 3 (Sometimes), 4 (Fairly often), and 5 (Frequently). The TTQ includes four subscales (each one made up of four items) to measure individualized consideration (e.g., 'Shows that s/he cares about me'), idealized influence (e.g., 'Acts as a person that I look up to'), intellectual stimulation (e.g., 'Creates lessons that really encourage me to think'), and inspirational motivation (e.g., 'Is enthusiastic about what I am capable of achieving').

Students' motivational regulations were assessed using the Spanish version (Moreno-Murcia, González-Cutre, \& Chillón, 2009) of the Perceived Locus of Causality Scale (Goudas, Biddle, \& Fox, 1994), in which students responded to 20 items (divided into five subscales made up of four items each) that measure intrinsic motivation (e.g., 'Because $\mathrm{PE}$ is fun'), identified regulation (e.g., 'Because I want to learn sport skills'), introjected regulation (e.g., 'Because I want the teacher to think I'm a good student'), external regulation (e.g., 'Because I'll get into trouble if I don't'), and amotivation (e.g., 'But I really don't know why'). The scale stem was 'I participate in this physical education class...' and the responses are rated on a 5 -point Likert scale ranging from 1 (Totally disagree) to 5 (Totally agree). Previous research has confirmed the reliability of the instrument both with Spanish (Moreno-Murcia et al., 2009) and English samples (Goudas et al., 1994).

To assess the perception of enjoyment and boredom, we used the Spanish version (Castillo, Balaguer, \& Duda, 2001) of the Intrinsic Satisfaction Classroom Scale (Duda \& Nicholls, 1992), adapted to PE classes. The instrument has seven items divided into two scales that measure Satisfaction/Enjoyment (five items; e.g., 'I usually enjoy learning at school') and Boredom (two items; e.g., 'I usually wish school would end quickly'). The students are requested to indicate their degree of agreement with the items rated on a 5-point Likert scale ranging from 1 (Totally disagree) to 5 (Totally agree). Previous research has confirmed the reliability of this instrument (Castillo et al., 2001; Duda \& Nicholls, 1992).

\section{Procedure}

Prior to conducting the study, ethical approval was obtained from the lead author's institutional review board. After selecting the schools randomly by area (simple random sampling) within the Authors' Community from the list provided by the Ministry of Education, Research, Culture and Sports, a letter was sent to the director of the schools, informing them about the goals of the investigation and requesting their collaboration. All the schools contacted expressed interest in participating in the investigation. All participants provided informed consent before data collection. The questionnaires were responded to anonymously and voluntarily, and were completed by the students during a 10 minute interval in their classroom. The questionnaires were administered by at least one investigator simultaneously to all the class members. Neither the teacher nor the director of the school was present at any time during questionnaire administration. Students were encouraged to answer honestly and ask the investigator present if they had any questions.

The source English version of the TTQ was translated to Spanish following the back-translation procedure widely described in the literature (e.g., Hambleton \& Kanjee, 1995). First, three native Spanish speakers independently translated the original English TTQ version into Spanish. Translation discrepancies among the three translated forms were discussed in order to develop an initial Spanish version of the questionnaire. Next, a second bilingual translator whose native language was English translated the initial Spanish version of the test back into English. The original and backtranslated versions of the tests were then compared. Finally, translation differences revealed by the back translation procedure were corrected. After the back-translation procedure had concluded, a pilot study was carried out in order to test the adequacy of the questionnaire for use with Spanish teenagers. No problems were found, so this version was adopted as the final Spanish version of the TTQ (the Spanish version of the questionnaire can be obtained from the first author).

\section{Statistical and Psychometric Analysis}

Sample 1 was used to test factorial structure through exploratory factor analysis (EFA) and internal consistency. An independent sample (sample 2) was used to cross-validate the internal structure of the TTQ using confirmatory factor analysis (CFA), estimate the reliability of the scale's scores, analyse gender invariance, and provide sources of validity based on relationships with other variables.

In both samples Cronbach's alpha coefficient, Average Variance Extracted (AVE) and composite reliability value (rho) were estimated to evaluate internal consistency. For EFA, unweight least square was chosen as the extraction method, and an oblique rotation criterion was applied (Lloret-Segura, Ferreres-Traver, Hernández-Baeza, \& TomásMarco, 2014; Sass \& Schmitt, 2010). These analyses were carried out using SPSS 20.

CFA were carried out with LISREL 8.80. Considering the ordinal nature of the items, weighted least squares was used to estimate model parameters, and the polychoric correlation matrix and the asymptotic covariance matrix were used as input for the analyses. Hu and Bentler's (1999) criteria $(\mathrm{NNFI}$ and $\mathrm{CFI} \geq .95, \mathrm{RMSEA} \leq .08)$ and $\chi^{2} / \mathrm{df}<5$ (Byrne, 1989) were applied to indicate good fit.

In Study 2 a sequential model testing approach was employed via multi-sample CFA to examine whether the TTQ displayed invariance across gender. A decrease in CFI and NNFI larger than .01 from one model to the next was taken to indicate that the more constrained model was not invariant across the samples (Cheung \& Rensvold, 2002). Similarly, Chen (2007) suggested RMSEA increases of less than .015 between alternative models indicate irrelevant differences. 


\section{Results}

\section{Descriptive Analysis and Exploratory Factor Analy- sis (Study 1)}

The descriptive statistics are offered in Table 1. EFA results showed a one-factor solution that accounted for $60.7 \%$ of common variance. All items' factor loading were higher than .61. The scale demonstrated good internal consistency $(\alpha=.96, \mathrm{AVE}=.61$, rho $=.96)$.

\section{Confirmatory Factor Analysis (Study 2)}

Considering the results obtained in the EFA carried out in Study 1, two alternative models were tested: A one-factor model and a four-factor model. The single-factor model showed satisfactory fit: $\chi^{2}(104)=390.88, p<.01 ; \chi^{2} / \mathrm{df}=$ 3.76; RMSEA $=.051$; NNFI $=.974$; CFI $=.977$. The items' factor loadings ranged from .76 to .95 , all statistically significant $(p<.01)$. The transformational teaching factor demonstrated good internal consistency $(\alpha=.96, \mathrm{AVE}=.81$, rho $=$ $.99)$.

Table 1. Descriptive statistics, univariate normality and item-factor loading for all the Transformational Teaching Questionnaire responses (Study $1, n=$ 1066).

\begin{tabular}{|c|c|c|c|c|c|c|}
\hline & & Mean & $S D$ & Skew & Kurtosis & Item-Factor Loading \\
\hline 1 & Demuestra que se preocupa por mí [Shows that s/he cares about me] & 3.75 & 1.10 & -0.61 & -0.26 & .80 \\
\hline 2 & Actúa como un modelo para mí [Acts as a person that I look up to] & 3.32 & 1.24 & -0.34 & -0.77 & .79 \\
\hline 3 & $\begin{array}{l}\text { Da las clases de forma que me invita a pensar [Creates lessons that real- } \\
\text { ly encourage me to think] }\end{array}$ & 3.32 & 1.18 & -0.34 & -0.62 & .75 \\
\hline 4 & $\begin{array}{l}\text { Demuestra que él/ella cree en mí [Demonstrates that s/he believes in } \\
\text { me] }\end{array}$ & 3.66 & 1.21 & -0.69 & -0.37 & .84 \\
\hline 5 & $\begin{array}{l}\text { La forma que tiene de tratarme hace que se gane mi respeto [Treats me } \\
\text { in ways that build my respect] }\end{array}$ & 3.89 & 1.16 & -0.92 & 0.06 & .81 \\
\hline 6 & $\begin{array}{l}\text { Es entusiasta sobre lo que soy capaz de lograr [Is enthusiastic about } \\
\text { what I am capable of achieving] }\end{array}$ & 3.60 & 1.19 & -0.63 & -0.35 & .81 \\
\hline 7 & $\begin{array}{l}\text { Me plantea tareas y retos que me hacen pensar de diferentes maneras } \\
\text { [Provides me with tasks and challenges that get me to think in different } \\
\text { ways] }\end{array}$ & 3.44 & 1.18 & -0.44 & -0.49 & .79 \\
\hline 8 & Me motiva a esforzarme al máximo [Motivates me to try my hardest] & 3.85 & 1.19 & -0.86 & -0.11 & .82 \\
\hline 9 & $\begin{array}{l}\text { Trata de conocer a todos los alumnos de la clase [Tries to know every } \\
\text { student in the class] }\end{array}$ & 3.97 & 1.11 & -0.99 & 0.27 & .68 \\
\hline 10 & $\begin{array}{l}\text { Me lleva a cuestionarme mis propias ideas y las de los demás [Gets me } \\
\text { to question my own and others'ideas] }\end{array}$ & 3.14 & 1.13 & -0.23 & -0.58 & .74 \\
\hline 11 & $\begin{array}{l}\text { Trata de ayudar a los alumnos que pueden sentirse frustrados o blo- } \\
\text { queados [Tries to help students who might be struggling] }\end{array}$ & 3.93 & 1.12 & -1.02 & 0.42 & .79 \\
\hline 112 & Habla de sus valores personales [Talks about his/her personal values] & 3.06 & 1.24 & -0.13 & -0.85 & .62 \\
\hline 13 & $\begin{array}{l}\text { Me anima a ver los asuntos desde diferentes perspectivas [Encourages } \\
\text { me to look at issues from different sides] }\end{array}$ & 3.34 & 1.17 & -0.34 & -0.60 & .80 \\
\hline 14 & $\begin{array}{l}\text { Reconoce las necesidades y capacidades de cada alumno en la clase } \\
\text { [Recognizes the needs and abilities of each student in the class] }\end{array}$ & 3.74 & 1.14 & -0.78 & -0.03 & .76 \\
\hline 15 & $\begin{array}{l}\text { Es optimista sobre lo que puedo lograr [Is optimistic about what I can } \\
\text { accomplish] }\end{array}$ & 3.80 & 1.17 & -0.85 & -0.04 & .84 \\
\hline 16 & $\begin{array}{l}\text { Se comporta como alguien en quien puedo confiar [Behaves as someo- } \\
\text { ne I can trust] }\end{array}$ & 3.75 & 1.23 & -0.79 & -0.28 & .81 \\
\hline
\end{tabular}

Note. Range 1-5.

The four-factor model adequately fitted the data: $\chi^{2}$ (98) $=344.11, p<.01 ; \chi^{2} / \mathrm{df}=3.51 ; \mathrm{RMSEA}=.049 ; \mathrm{NNFI}=$ .976 ; CFI $=.980$. The items' factor loadings ranged from .75 to .95 , all statistically significant $(p<.01)$. The four subscales demonstrated good internal consistency, with Cronbach's alpha values ranging from .85 to .90, AVE values ranging from .77 to .87 , and rho values ranging from .83 to .96 . Table 2 shows descriptive statistics, reliability indices, and correlations among the TTQ subscales. The four subscales were found to be highly correlated $(.83>r>.74)$; however, considering that factor discrimination can be established when inter-factor correlations are below .85 (Kline, 2005), results showed that TTQ inter-factor correlations supported factor discrimination.

Following the results of the CFA (supporting the unidimensional model), but also the results providing evidence for the factor discrimination of the four dimensions of the scale, and consistent with Beauchamp and colleagues (2010), a four-factor second-order model with the four transformational teaching dimensions specified as contributing towards a higher order factor (termed transformational teaching) was also tested. 
The proposed four-factor second-order model adequately fitted the data: $\chi^{2}(100)=349.29, p<.01 ; \chi^{2} / \mathrm{df}=3.49$; RMSEA $=.049 ;$ NNFI $=.976 ;$ CFI $=.980$. The items' factor loadings ranged from .75 to .95 , all statistically significant $(p$ $<.01)$.

\section{Evidence of validity based on relationships with other variables (Study 2)}

Results revealed a significant and positive correlation between the most self-determined forms of motivations (intrinsic motivation, identified regulation and introjected regulation) and enjoyment with the four subscales of transformational teaching and the total score scale, and negative correlations with the lowest forms of motivation (external regulation and amotivation) and with boredom (see Table 3).

Table 2. Descriptive statistics, reliability and Pearson correlations between Transformational Teaching Questionnaire subscales (Study $2, n=1041)$.

\begin{tabular}{lcccccccc}
\hline & Mean & $S D$ & $\alpha$ & AVE & rho & 1 & 2 & 3 \\
\hline 1. Individualized Consideration & 3.86 & 0.92 & .85 & .79 & .94 & - & & \\
2. Idealized Influence & 3.52 & 0.96 & .87 & .77 & .93 & $.83^{* *}$ & - & \\
3. Intellectual Stimulation & 3.32 & 0.97 & .86 & .78 & .93 & $.74^{* *}$ & $.81^{* *}$ & - \\
4. Inspirational Motivation & 3.72 & 1.03 & .90 & .87 & .96 & $.82^{* *}$ & $.83^{* *}$ & $.77^{* *}$ \\
\hline
\end{tabular}

Note. Range 1-5. $\alpha=$ Cronbach alpha. AVE = average variance extracted value; rho = composite reliability value. Following Table 1: Individualized Consideration (items 1, 9, 11, 14); Idealized Influence (items 2, 5, 12, 16); Intellectual Stimulation (items 3, 7, 10, 13); and Inspirational Motivation (items 4, 6, 8, 15).

$$
* * p<.01
$$

Table 3. Descriptive statistics, reliability and Pearson correlations of Transformational Teaching Questionnaire subscales and total scale with the theoretical outcome measures (Study 2, $n=1041$ ).

\begin{tabular}{|c|c|c|c|c|c|c|c|c|}
\hline & Mean & $S D$ & $\alpha$ & $\mathrm{IC}$ & II & IS & IM & $\mathrm{TT}$ \\
\hline Intrinsic Motivation & 3.71 & 0.82 & .83 & $.47 * *$ & $.45^{* *}$ & $.49 * *$ & $.49 * *$ & $.52 * *$ \\
\hline Identified Regulation & 3.71 & 0.83 & .83 & $.41 * *$ & $.40^{* *}$ & $.45^{* *}$ & $.47 * *$ & $.47 * *$ \\
\hline Introjected Regulation & 3.13 & 0.79 & .67 & $.19 * *$ & $.26 * *$ & $.30 * *$ & $.28 * *$ & $.28 * *$ \\
\hline External Regulation & 2.83 & 0.91 & .71 & $-.21 * *$ & $-.14 * *$ & $-.12^{* *}$ & $-.19 * *$ & $-.18^{* *}$ \\
\hline Amotivation & 2.22 & 1.02 & .83 & $-.30 * *$ & $-.22 * *$ & $-.20 * *$ & $-.29 * *$ & $-.28 * *$ \\
\hline Enjoyment & 3.61 & 0.78 & .81 & $.52^{* *}$ & $.51 * *$ & $.52^{* *}$ & $.56 * *$ & $.57^{* *}$ \\
\hline Boredom & 2.13 & 1.03 & .78 & $-.38 * *$ & $-.34 * *$ & $-.32 * *$ & $-.40 * *$ & $-.39 * *$ \\
\hline
\end{tabular}

Note. Range 1-5. IC = Individualized Consideration; II = Idealized Influence; IS = Intellectual Stimulation; IM = Inspirational Motivation; TT = Total Transformational Teaching.

** $p<.01$

\section{One-factor Measurement Invariance (Study 2)}

CFA results (see Table 4) revealed that the proposed factorial structure was acceptable for each gender group considered separately (Models $\mathrm{M0a}$ and M0b), as well as for the multi-sample baseline model (Model 1). Model 1 was used as the baseline against which all remaining models were compared in the process of determining evidence of invariance.

Model 2 (M2) tested whether all factor loadings were invariant across gender. The practical fit indices showed that this model has a reasonable fit (see Table 4), except for RMSEA value. However, the incremental fit indexes indicated that the total invariance factor loading hypothesis might not be tenable. Items with higher modification indexes for factor loading parameter were set free in a sequence of nested models. Factor loadings of item 16 ('Behaves as someone I can trust') and item 11 ('Tries to help students who might be struggling') were detected as non-invariant across gender (see Model M2a and M2b in Table 4).
Model 3 (M3) tested partial factor loadings invariance and total intercept invariance hypothesis. The practical fit indices showed that this model has a reasonable fit (see Table 4). However, the incremental fit indexes indicated that this hypothesis might not be tenable. We looked for the item with the highest modification index for the intercept parameter. Intercept of item 9 ('Tries to know every student in the class') was detected as non-invariant across gender (see Model M3a in Table 4).

Measurement invariance analysis indicated that not all the item parameters were invariant across gender; concretely items 9, 11 and 16 were detected to show differential item functioning (DIF). The practical significance of the DIF detected across gender was tested. The mean score on the TTQ, with and without removing items 9, 11 and 16 was computed for each gender group and compared across groups using the standardized mean difference. The DIF is considered trivial when the $d$ value is lower than .20 (Chan, 2000). In the present study, the $d$ difference was .004. 
Table 4. Goodness of fit indices for tested invariance models across gender (Study 2, $n=1041$ ).

\begin{tabular}{|c|c|c|c|c|c|c|c|c|c|}
\hline Model & Description & $\chi^{2}$ & df & NNFI & CFI & RMSEA & $\triangle \mathrm{NNFI}$ & $\Delta \mathrm{CFI}$ & $\triangle \mathrm{RMSEA}$ \\
\hline $\mathrm{M} 0 \mathrm{a}$ & Baseline Model - Men & $126.43^{* *}$ & 104 & .977 & .980 & .049 & & & \\
\hline $\mathrm{MOb}$ & Baseline Model - Women & $200.04^{* *}$ & 104 & .985 & .987 & .059 & & & \\
\hline M1 & Baseline Model Structural Invariance & $534.47^{* *}$ & 208 & .982 & .985 & .055 & & & \\
\hline M2 & Factor Loading (FL) Invariance & $2230.54 * *$ & 224 & .900 & .907 & .132 & .082 & .078 & .077 \\
\hline M2a & Partial FL Invariance (FL item 16 set free) & $821.27 * *$ & 223 & .969 & .972 & .073 & .013 & 0.13 & .018 \\
\hline M2b & Partial FL Invariance (FL item 16 \& 11 set free) & $741.67 * *$ & 222 & .973 & .976 & .065 & .009 & .009 & .010 \\
\hline M3 & $\mathrm{M} 2 \mathrm{~b}+$ Intercept (IN) Invariance & $932.07 * *$ & 237 & .965 & .967 & .077 & .017 & .018 & .022 \\
\hline M3a & M2b + Partial IN Invariance (IN item 9 set free) & $718.52 * *$ & 235 & .975 & .977 & .065 & .007 & .008 & .010 \\
\hline
\end{tabular}
Note. ${ }^{* *} p<.01$

\section{Discussion and Conclusion}

The purpose of this study was to translate into Spanish and examine the psychometric properties of the Transformational Teaching Questionnaire (TTQ) in adolescents in PE context. Concretely, reliability, factorial structure, validity based on the relationships with other variables, and measurement invariance across gender were tested. Overall, the TTQ exhibited good psychometrics properties in the Spanish samples.

CFA results suggested that the four transformational teaching dimensions, specified as contributing towards a higher order factor named 'transformational teaching', adequately reflects the underlying factor structure of the TTQ, consistently with findings in the literature (see Beauchamp et al., 2010). Nevertheless, results suggested the one-factor and the four-factor models fit the data relatively well. So, researchers can use the different options depending on the research questions.

Results indicated that the single-factor model of the TTQ was invariant across gender. Partial strong factorial invariance (was supported; and the DIF detected showed to be irrelevant. Thus, it was concluded that Spanish adolescents responded in a similar fashion independently of the gender. These findings indicate the Spanish version of the TTQ is a valid scale to assess transformational teaching in PE for both male and female students, and allows for unbiased comparison of average scores in the two gender groups.

As in previous studies (i.e., Beauchamp et al., 2010; Beauchamp \& Morton, 2011; Wilson et al., 2012), students' perception of transformational teaching were positively related to the most self-determined forms of motivation and enjoyment, and negatively associated with the lowest selfdetermined forms of motivation and boredom. In other words, when students perceived that their teachers use transformational behaviors they informed to be more selfdetermined motivated, more satisfied in school and less bored. In this sense, self-determined motivation and enjoyment derived from PE have been demonstrated that are best determinants of intention to be physically active (e.g., Quested et al., 2013) and robust predictors of PA at both younger and older ages (Sallis, Prochaska, \& Taylor, 2000). PE teachers should provide enjoyable PE experiences to positively influence adolescent involvement in health-enhancing behaviors. Understanding the influence of school PE teachers' transformational behaviors on adolescent's cognitive, affective and behavioral outcomes is a key factor to enhance students' PA inside and outside the school (e.g., Beauchamp \& Morton, 2011). Hence to assess transformational teaching in the PA context represents a particularly worthwhile research endeavor.

There are some limitations in our study. First, we cannot generalize this scale to other Spanish age groups, as participants in current study are adolescents ranging from 16 to 18 years old. Future research need to test whether Spanish version of the TTQ is also suitable for measuring perceptions of transformational leadership in other age groups. Second, this study showed that the factor invariance holds across gender groups, however, testing measurement invariance across other target groups (e.g., age groups) would be issues for future investigation, to determine the extent to which the TTQ can be considered a valid measure for carrying out comparison studies of the perceptions of transformational teaching across other groups. Though these limitations, our findings suggested that the Spanish version of TTQ would be useful for assessing transformational teaching in Spanish adolescents, and also for carrying out comparison studies across gender groups.

Finally, our study has a number of theoretical and practical implications. Firstly, results have substantive importance for transformational leadership theory, as they provide evidence for the cross-cultural validation of the TTQ, a questionnaire designed to assess students' perceptions of their teachers' behaviours from the perspective of transformational leadership theory (Bass, 1985); and secondly this study provides a valid, reliable and efficient instrument which can be used in broader survey studies or intervention studies with Spanish adolescents in the context of PA and PE. 


\section{References}

Álvarez, O., Castillo, I., Molina-García, V., \& Balague, G. (2016). Transformational leadership on the athletic field: An international review. Revista de Psicología del Deporte, 25, 319-326.

Álvarez, O., Lila, M., Tomás, I., \& Castillo, I. (2014). Transformational Leadership in the Local Police in Spain: A leader-follower distance approach. Spanish Journal of Psychology, 17(e42), 1-9. http://dx.doi.org/10.1017/sip.2014.44

Antonakis, J., Schriesheim, C. A., Donovan, J. A., Gopalakrishna-Pillai, K., Pellegrini, E. K., \& Rossomme, J. (2004). Methods for studying leadership. In J. Antonakis, A. T. Cianciolo, \& R. J. Sternberg (Eds.), The nature of leadership (pp. 48-70). Thousand Oaks, CA: Sage Publications.

Balluerka, N., Gorostiaga, A., Alonso-Arbiol, I., \& Haranburu, M. (2007). La adaptación de instrumentos de medida de unas culturas a otras: una perspectiva práctica [Test adaptation to other cultures: A practical approach]. Psicothema, 19, 124-133.

Barling, J., Christie, A., \& Hoption, C. (2011). Leadership. In S. Zedeck (Ed.), AP A bandbook of industrial and organizational psychology: Vol 1. Building and developing the organization (pp. 183-240). Washington, DC: American Psychological Association. http://dx.doi.org/10.1037/12169-007

Bass, B. M. (1985). Leadership and performance beyond expectations. New York, NY: Free Press.

Bass B. M., \& Avolio B. J. (1995). MLQ Multifactor Leadership Questionnaire: Sampler set. Redwood City, CA: Mind Garden.

Bass, B. M., \& Riggio, R. E. (2006). Transformational Leadership. Mahwah, NJ: Erlbaum.

Beauchamp, M. R., \& Morton, K. L. (2011). Transformational teaching and physical activity engagement among adolescents. Exercise and Sport Sciences Reviews, 39, 133-139. http://dx.doi.org/10.1097/JES.0b013e31822153e7

Beauchamp, M. R., Barling, J., Li, Z., Morton, K. L., Keith, S. E., \& Zumbo, B. D. (2010). Development and psychometric properties of the transformational teaching questionnaire. Journal of Health Psychology, 15, 1123-1134. http://dx.doi.org/10.1177/1359105310364175

Beauchamp, M. R., Liu, Y., Morton, K. L., Martin, L. J., Wilson, A. H., Wilson, A. J. \& Barling, J. (2014). Transformational teaching and adolescent physical activity: Multilevel and mediational effects. International Journal of Behavioral Medicine, 21, 537-546. http://dx.doi.org/10.1007/s12529-013-9321-2

Burns, J. M. (1978). Leadership. New York, NY: Harper \& Row.

Byrne, B. M. (1989). A primer of LISREL: Basic applications and programming for confirmatory factor analytic models. New York, NY: Springer-Verlag.

Castillo, I., Balaguer, I., \& Duda, J. L. (2001). Perspectivas de meta de los adolescentes en el contexto académico [Goal perspectives of adolescents in academic context). Psicothema, 13(1), 79-86.

Chan, D. (2000). Detection of differential item functioning on the Kirton Adaption-Innovation Inventory using multiple-group mean and covariance structure analyses. Multivariate Behavioral Research, 35, 169-199. https://doi.org/10.1207/S15327906MBR3502_2

Chen, F. F. (2007). Sensitivity of goodness of fit indexes to lack of measurement invariance. Structural Equation Modeling, 14, 464-504. http:/ / dx.doi.org/10.1080/10705510701301834

Cheung, G. W., \& Rensvold, R. B. (2002). Evaluating goodness-of-fit indexes for testing MI. Structural Equation Modeling, 9, 235-255. http://dx.doi.org/10.1207/s15328007sem0902_5

Densten I. L. (2003). Senior police leadership: Does rank matter? Policing: An International Journal of Police Strategies \& Management, 26, 400-418. http:/ /dx.doi.org/10.1108/13639510310489467

Duda, J. L., \& Nicholls, J. G. (1992). Dimensions of achievement motivation in schoolwork and sport. Journal of Educational Psychology, 84, 290299. http://dx.doi.org/10.1037/0022-0663.84.3.290
Goudas, M., Biddle, S., \& Fox, K. (1994). Perceived locus of causality, goal orientations, and perceived competence in school physical education classes. British Journal of Educational Psychology, 64, 453-463.

Hambleton, R. K., \& Kanjee, A. (1995). Increasing the validity of crosscultural assessments: Use of improved methods for test adaptations. European Journal of Psychological Assessment, 11, 147-157. http://dx.doi.org/10.1027/1015-5759.11.3.147

Hu, L., \& Bentler, P. M. (1999). Cutoff criteria for fit indexes in covariance structure analysis: conventional criteria versus new alternatives. Structural Equation Modeling: A Multidisciplinary Journal, 6, 1-55. http://dx.doi.org/10.1080/10705519909540118

Kline, R. B. (2005). Principles and practice of structural equation modeling. New York, NY: Guilford Press.

Lloret-Segura, S., Ferreres-Traver, D., Hernandez-Baeza, A., \& TomasMarco, I. (2014). El análisis factorial exploratorio de los ítems: Una guía práctica, revisada y actualizada [Exploratory item factor analysis: A practical revised and updated guide]. Anales de Psicología, 30, 1151-1169. http://dx.doi.org/10.6018/analesps.30.3.199361.

Molero, F., Cuadrado, I., Navas, M., \& Morales, F. L. (2007). Relations and effects of transformational leadership: A comparative analysis with traditional leadership styles. The Spanish Journal of Psychology, 10, 358-368.

Molero, F., Recio, P., \& Cuadrado, I. (2010). Liderazgo transformacional y liderazgo transaccional: Un análisis de la estructura factorial del Multifactor Leadership Questionnaire (MLQ) en una muestra española. Psicothema, 22, 495-501.

Molina-García, J., Queralt, A., Estevan, I., \& Sallis, J. F. (2016). Ecological correlates of Spanish adolescents' physical activity during physical education classes. European Physical Education Review, 22, 479-489. https://doi.org/10.1177/1356336X15623494

Moreno-Murcia, J. A., González-Cutre, D., \& Chillón, M. (2009). Preliminary validation in Spanish of a scale designed to measure motivation in physical education classes: the Perceived Locus of Causality (PLOC) Scale. The Spanish Journal of Psychology, 12, 327-337. https://doi.org/10.1017/S1138741600001724

Muñiz, J., Elosua, P., \& Hambleton, R. K. (2013). Directrices para la traducción y adaptación de los tests: segunda edición [International Test Commission guidelines for test translation and adaptation: Second edition]. Psicothema, 25(2), 151-157.

Quested, E., Ntoumanis, N., Viladrich, C., Haug, E., Ommundsen, Y., Van Hoye, A., Duda, J. L. (2013). Intentions to drop-out of youth soccer: A test of the basic needs theory among European youth from five countries. International Journal of Sport and Exercise Psychology, 11, 395-407. https://doi.org/10.1080/1612197X.2013.830431

Sallis, J. F., Prochaska, J. J., \& Taylor, W. C. (2000). A review of correlates of physical activity of children and adolescents. Medicine and Science in Sports and Exercise, 32, 963-975.

Sass, D. A., \& Schmitt, T. A. (2010). A comparative investigation of rotation criteria within exploratory factor analysis. Multivariate Behavioral Research, 45, 73-103. http://dx.doi.org/10.1080/00273170903504810

Wilson, A. J., Liu, Y., Keith, S. E., Wilson, A. H., Kermer, L. E., Zumbo, B. D., \& Beauchamp, M. R. (2012). Transformational teaching and child psychological needs satisfaction, motivation, and engagement in elementary school physical education. Sport, Exercise, and Performance Psychology, 1, 215-230. http://dx.doi.org/10.1037/a0028635

World Health Organization. (2010). Global recommendations on physical activity for health. Geneva: World Health Organization. http://www.who.int/dietphysicalactivity/publications/9789241599979 /en/

(Article received: 15-04-2017; revised: 28-07-2017; accepted: 18-10-2017) 